\title{
Protection of Terminalia belerica Roxb. Against Iron Overload Induced Liver Toxicity: An Account of Its Reducing and Iron Chelating Capacity
}

\author{
Bibhabasu Hazra, Rhitajit Sarkar and Nripendranath Mandal \\ Division of Molecular Medicine, Bose Institute, P-1/12 CIT Scheme VIIM, Kolkata-700054, India
}

Received 2012-04-27, Revised 2012-05-19; Accepted 2012-11-20

\begin{abstract}
Excess iron deposition in the liver catalyses the production of Reactive Oxygen Species (ROS) which in turn initiate oxidative damage of protein and nucleic acids leading to several human diseases. The fruits of Terminalia Belerica Roxb. (TB) has been most commonly used not only in stimulating gastrointestinal health, but also in treatment of various hepatic disorders. The present study was aimed to evaluate the ameliorating effect of 70\% methanol extract of TB (TBME) on iron overload induced liver injury, along with its in vitro iron chelating and DNA protection studies. Iron overload was induced by intraperitoneal administration of iron-dextran into mice. The biochemical markers of hepatic damage, liver iron, protein carbonyl and hydroxyproline content were measured in response to the oral administration of TBME. The reductive release of ferritin iron by TBME was further studied. The extract exhibited significant iron chelation with $\mathrm{IC}_{50}$ of $27.70 \pm 2.27 \mu \mathrm{g} \mathrm{mL}^{-1}$ and considerable DNA protection with $[\mathrm{P}]_{50}$ of $1.30 \pm 0.01 \mu \mathrm{g}$ $\mathrm{mL}^{-1}$. Treatment with different doses (50,100 and $200 \mathrm{~kg}$ body weight) of TBME showed dose dependent reduction in liver iron, lipid peroxidation, protein oxidation, liver fibrosis, serum enzymes and ferritin. The antioxidant enzymes levels were enhanced and the reductive release of ferritin iron increased significantly with gradually increasing concentrations of TBME. From the present results, it appears possible to support that TBME represents beneficial effects on iron overload mediated liver toxicity and hence possibly useful as iron chelating drug for iron overload diseases.
\end{abstract}

Keywords: Ferritin, Iron Overload, Lipid Peroxidation, Liver, Protein Carbonyl, Terminalia Belerica

\section{INTRODUCTION}

The liver is considered to be one of the most vital organs functioning as a centre of nutrient metabolism and waste metabolite excretion. Hepatic damage is associated with distortion of these metabolic functions (Wolf, 1999) and sometimes, resulting in the serious health problems. Hepatotoxicity is the most common finding in patients with iron overloading as liver is mainly responsible for taking up and storing excessive amount of iron (Papanastasiou et al., 2000). Iron, the most abundant transition metal in the body, is required by all mammalian cells for growth and survival. But, sometimes, extreme iron deposition increases oxidative stress in the liver and will lead to further injuries such as hepatocellular necrosis (Olynyk et al., 1995), inflammation (Deugnier et al., 1992), fibrosis (Gardi et al., 2002; Arezzini et al., 2003) and even to cancer (Niederau et al., 1985). In all iron overload induced diseases, iron removal by iron chelation therapy is an effective lifesaving strategy. The iron chelating agents currently available for clinical use are deferoxamine, 1,2dimethyl-3-hydroxypyrid-4-one (deferiprone, L1) and deferasirox. However, such compounds are inadequate and exert several side effects and disadvantages (AlRefaie et al., 1992; Kontoghiorghes, 2003). In view of severe undesirable side effects of synthetic agents, there is growing focus to develop more effective and safe 
drugs (Zhang et al., 2006; Pardo-Andreu et al., 2008) which may raise the therapeutic benefits for patients.

Phenolics and flavonoids are plant metabolites widely spread throughout the plant kingdom. It has been found that most of them are effective antioxidants (RiceEvans et al., 1996; Lopez et al., 2003) and iron chelation is very important part of their antioxidant activity (Cook and Samman, 1996). Phenolics and flavonoids therefore, could have a double, synergistic action, making them into effective antioxidants, particularly active in pathological situations involving iron overload, e.g. $\beta$ thalassemia, Friedreich's ataxia and hemochromatosis.

Terminalia Belerica (TB) (Gaertn.) Roxb. (FamilyCombertaceae), popularly known as 'Belleric myrobalan', is a deciduous tree growing wild throughout the Indian subcontinent, Sri Lanka and south-east Asia. It is an integral part of traditional laxative formulation, 'Triphala' which is used for a huge variety of ailments for generations in Ayurvedic medicine (Chopra, 1956). $\mathrm{TB}$ is commonly used in treatment of various gastrointestinal complaints (Kapoor, 2001) and a variety of throat disorders, including cough, hoarseness, as well as eye disorders. The astringent nature of the dried fruit is also used in cases of dropsy, piles and diarrhoea (Kapoor, 2001). Chemically, the presence of phenolics, sugars, gallic acid, belleric acid and $\beta$-sitosterol in the fruits of TB has been reported (Row and Murthy, 1970). The dried fruits of TB possesses potential antimicrobial (Madani and Jain, 2008), anti-diabetic (Sabu and Kuttan, 2009) and anti-atherosclerotic (Shaila et al., 1995) activity. TB is also reported to have hepatoprotective effects against carbon tetrachloride induced liver toxicity (Anand et al., 1994; 1997; Jadon et al., 2007). Previously, the free radical scavenging and reducing property of $70 \%$ methanol extract of TB (TBME) has been reported with the finding of significant amount of phenolic and flavonoid compounds (Hazra et al., 2010). Based on these observations, the present study is performed to assess in vitro iron chelating activity of TBME and whether this activity along with reducing power can normalise the damage caused to liver by iron overload.

\section{MATERIALS AND METHODS}

\subsection{Chemicals}

Iron-dextran and guanidine hydrochloride were purchased from Sigma-Aldrich, USA. Trichloroacetic Acid (TCA), Nitro Blue Tetrazolium (NBT), reduced Nicotinamide Adenine Dinucleotide (NADH), Phenazine Methosulfate (PMS), ferrozine, glutathione reduced, bathophenanthroline sulfonate disodium salt, Thiobarbituric Acid (TBA), L-Ascorbic acid and 5,5'Dithiobis-2-Nitrobenzoic Acid (DTNB) were obtained from Sisco Research Laboratories Pvt. Ltd, Mumbai, India. Hydrogen peroxide, $\mathrm{KCl}$, ammonium iron (II) sulfate hexahydrate $\left[\left(\mathrm{NH}_{4}\right)_{2} \mathrm{Fe}\left(\mathrm{SO}_{4}\right)_{2} 6 \mathrm{H}_{2} \mathrm{O}\right]$, 1-chloro2,4-dinitrobenzene (CDNB), chloramine-T, hydroxylamine hydrochloride, Dimethyl-4aminobenzaldehyde and 2,4-Dinitrophenylhydrazine (DNPH) were obtained from Merck, Mumbai, India. Ferritin was purchased from MP Biomedicals, USA. Streptomycin sulphate and N-(2Hydroxyethyl)piperazine-N'-2-ethanesulphonic acid (HEPES buffer) were obtained from HiMedia Laboratories Pvt. Ltd, Mumbai, India. The standard oral iron chelating drug, desirox (parent group deferasirox), was obtained from Cipla Ltd., Kolkata, India. Desferal (deferoxamine mesylate USP), was obtained from Novartis, USA.

\subsection{Plant Material}

The fruits of Terminalia Belerica (TB) were collected from the Bankura district of West Bengal, India. It was identified and authenticated through the Central Research Institute (Ayurveda), Kolkata, India and a voucher specimen (CRHS 114/08) was submitted there.

\subsection{Animals}

Male Swiss albino mice $(20 \pm 2 \mathrm{~g})$ were purchased from Chittaranjan National Cancer Institute (CNCI), Kolkata, India and were maintained under a constant 12 $\mathrm{h}$ dark/light cycle at an environmental temperature of $22 \pm 2^{\circ} \mathrm{C}$. The animals were provided with normal laboratory pellet diet and water ad libitum. All experiments were performed after obtaining approval from the institutional animal ethics committee and care of the animals was taken as per the guidelines of the Committee for the Purpose of Control and Supervision of Experiments on Animals (CPCSEA), Ministry of Environment and Forest, Government of India.

\subsection{Extract Preparation}

The fruits of TB were dried at room temperature for 7 days, finely powdered and used for extraction. The powder $(100 \mathrm{~g})$ was mixed with $500 \mathrm{~mL}$ methanol: Water (7:3) using a magnetic stirrer for $15 \mathrm{~h}$, then the mixture was centrifuged at $2850 \mathrm{~g}$ and the supernatant was decanted. The process was repeated again with the precipitated pellet. The supernatants were collected, concentrated in a rotary evaporator and lyophilized. The dried extract was stored at $-20^{\circ} \mathrm{C}$ until use. A $46.8 \%$ yield of the extract was obtained. 


\subsection{In vitro Study \\ 2.5.1. Iron Chelation}

The $\mathrm{Fe}^{2+}$ chelating activity of TBME was evaluated according to a standard method (Haro-Vicente et al., 2006). In a HEPES buffer ( $20 \mathrm{mM}, \mathrm{pH}$ 7.2) medium, TBME (0-120 $\left.\mu \mathrm{g} \mathrm{mL}^{-1}\right)$ and positive control EDTA (0$20 \mu \mathrm{g} \mathrm{mL}^{-1}$ ) were separately added to a $12.5 \mu \mathrm{M}$ ferrous sulfate solution and $75 \mu \mathrm{M}$ ferrozine was added to start reaction. The mixture was shaken vigorously and left standing for $20 \mathrm{~min}$ at room temperature and then the absorbance was taken at $562 \mathrm{~nm}$. All tests were performed six times.

\subsection{DNA Protection}

pUC18 plasmid DNA was used for DNA protection study by TBME, according to a previously described method with minor modifications (Hermes-Lima et al., 1998). In HEPES buffer (pH 7.2, $100 \mathrm{mM}), \mathrm{FeSO}_{4}$ solution $(750 \mu \mathrm{M})$, TBME of varying doses $(0-5 \mu \mathrm{g}$ $\left.\mathrm{mL}^{-1}\right)$, DNA $\left(0.5 \mathrm{mg} \mathrm{mL}^{-1}\right)$ and water were added to make an initial reaction mixture. Finally, $\mathrm{H}_{2} \mathrm{O}_{2}$ solution $(7.5 \mathrm{mM})$ was added to start the reaction. Desferal $(0.2$ $\mathrm{mM}$ ) was used to stop the reaction after $10 \mathrm{~min} .25 \mu \mathrm{L}$ of each reaction mixture was loaded in $1 \%$ agarose gel. After migration, the gel was stained with ethidium bromide and visualized in a UV transilluminator. The DNA bands were quantified through densitometry, with the parameter Volume = Intensity X Area and the following formulae were used to calculate the percentage of protection:

$\% \mathrm{SC}=[1.4 \times \mathrm{SC} /(\mathrm{OC}+(1.4 \times \mathrm{SC}))] \times 100$

where, $\mathrm{SC}=$ supercoiled; $\mathrm{OC}=$ open circular; $1.4=$ correction factor $\%$ protection $=100 \mathrm{X}[$ (control SCchelator SC)/(control SC-no chelator SC) -1].

The ability of the plant extract to protect the DNA supercoil can be expressed by the concentration of sample required for $50 \%$ protection, designated as the $[\mathrm{P}]_{50}$ value.

\subsection{In Vivo Study}

\subsubsection{Experimental Design}

Out of six groups each comprising of six mice, one group received normal saline only and served as Blank (B). The mice of other five groups were i.p injected with $100 \mathrm{mg} \mathrm{kg}^{-1}$ b.w. each, of iron-dextran saline given five doses (one dose every two days). Normal saline was administered to one iron-dextran group (C) and other four groups were orally treated with $50 \mathrm{mg} \mathrm{kg}^{-1}$ b.w.
(S50), $100 \mathrm{mg} \mathrm{kg}^{-1}$ b.w. (S100), $200 \mathrm{mg} \mathrm{kg}^{-1}$ b.w. (S200) TBME and $20 \mathrm{mg} \mathrm{kg}^{-1}$ b.w. Desirox (D), respectively, for three consecutive 7 day periods, started from the day after the first iron-dextran injection.

\subsection{Sample Collection and Tissue Preparation}

At the end of oral treatment, mice were fasted overnight before sacrifice. Blood was collected by cardiac puncture post terminal anesthetization with ethyl ether. Blood sera were separated by centrifugation and stored at $-80^{\circ} \mathrm{C}$ until analysis. Blood cell from dissected liver was rinsed off with ice-cold saline. Half portion of the liver was cut, weighed and homogenized in 10 volume of $0.1 \mathrm{M}$ phosphate buffer $(\mathrm{pH}$ 7.4) containing 5 $\mathrm{mM}$ EDTA and $0.15 \mathrm{M} \mathrm{NaCl}$ and centrifuged at $8000 \mathrm{~g}$ for $30 \mathrm{~min}$ at $4^{\circ} \mathrm{C}$. Supernatant collected was used for the determination of lipid peroxidation, protein oxidation, hydroxyproline content and enzyme activities. Standard BSA graph was used to estimate the protein concentration in the homogenate by Lowry et al. (1951) method. The other half of the liver samples were weighed and digested with 1:1 mixture of sulphuric acid and nitric acid to analyze the iron content.

\subsection{Serum Enzymes}

Alanine Amino Transferase (ALAT), Aspartate Amino Transferase (ASAT) and billirubin in serum samples were measured using the commercial kits of Merck, Mumbai, India. Alkaline Phosphatase (ALP) was estimated using the kit supplied by Sentinel Diagnostics, Italy.

\subsection{Antioxidant Enzymes}

Superoxide Dismutase (SOD) was assayed by measuring the inhibition of the formation of blue colored formazan at $560 \mathrm{~nm}$ (Kakkar et al., 1984). Catalase (CAT) activity was measured through time course decomposition of $\mathrm{H}_{2} \mathrm{O}_{2}$ at $240 \mathrm{~nm}$ (Bonaventura et al., 1972). A formerly reported method was followed to determine Glutathione-S-Transferase (GST) based on the formation of GSH-CDNB conjugate (Habig et al., 1974). Reduced Glutathione (GSH) level was measured spectrophotometrically at $412 \mathrm{~nm}$ by a standard procedure (Ellman, 1959).

\subsection{Lipid Peroxidation Products}

Lipid peroxidation levels in liver homogenates were determined in terms of Thiobarbituric Acid Reactive Substances (TBARS), as an index of malondialdehyde accumulation, in accordance to a formerly reported method (Buege and Aust, 1978). 


\subsection{Protein Carbonyl Content}

Protein carbonyl, a marker of protein oxidation, was done according to a spectrophotometric method (Reznick and Packer, 1994). Briefly, $50 \mu \mathrm{L}$ streptomycin sulphate $(10 \% \mathrm{w} / \mathrm{v})$ was added to $450 \mu \mathrm{L}$ sample homogenate and then centrifuged at $2800 \mathrm{~g}$ for $15 \mathrm{~min}$. Then $200 \mu \mathrm{L}$ of the supernatant was incubated with the same volume of $10 \mathrm{mM} \mathrm{DNPH}$ in $2 \mathrm{M} \mathrm{HCl}$ at room temperature for 20 min. $10 \%$ cold TCA was added to end the reaction and precipitate the proteins that were washed with ethyl acetate-ethanol mixture $(1: 1)$ to remove unreacted DNPH. The final protein pellet was dissolved in $1 \mathrm{~mL} 6$ $\mathrm{M}$ guanidine hydrochloride solution and the absorbance was measured at $370 \mathrm{~nm}$, using the molar extinction coefficient of DNPH, $\varepsilon=2.2 \times 10^{-4} \mathrm{M}^{-1} \mathrm{~cm}^{-1}$.

\subsection{Hydroxyproline Content}

Liver fibrosis gives rise to collagen which is alternately represented by hydroxyproline content. Hydroxyproline of liver samples hydrolized in $6 \mathrm{M} \mathrm{HCl}$ was measured by Ehrlich's solution using a standard procedure (Bergman and Loxley, 1963). A standard curve $\left(\mathrm{R}^{2}=0.9907\right)$ of 4-hydroxy-L-proline was prepared and results were calculated after taking absorbances at $558 \mathrm{~nm}$. The collagen content was determined by multiplying amount of total hydroxyproline content in each sample by a factor of 7.69 (Kivirikko et al., 1967). Results are expressed as milligrams of collagen per liver (wet weight).

\subsection{Histopathological Study}

The liver samples were excised, washed with normal saline and processed separately for histological observations. Initially, the material was fixed in $10 \%$ buffered neutral formalin for $48 \mathrm{~h}$. A paraffin embedding technique was carried out and sections were taken at 50 $\mu \mathrm{m}$ thickness, stained with hematoxylin and eosin and examined microscopically for histopathological changes.

\subsection{Liver Iron and Serum Ferritin}

Liver iron was measured according to a formerly reported colorimetric method (Barry and Sherlock, 1971). Samples were incubated with bathophenanthroline sulfonate for $30 \mathrm{~min}$ at $37^{\circ} \mathrm{C}$ and absorbances were measured at $535 \mathrm{~nm}$. Serum ferritin levels were measured using enzyme-linked immunosorbent assay kit (from Monobind Inc., USA) according to the manufacturer's instructions.

\subsection{Iron Release from Ferritin}

Iron release assay was performed using ferrozine, a classic $\mathrm{Fe}^{2+}$-chelator, as previously described (Hynes and
Coinceanainn, 2002). The reaction mixture ( $3 \mathrm{~mL}$ final volume) contained $200 \mu \mathrm{g}$ ferritin, $500 \mu \mathrm{M}$ ferrozine, in $50 \mathrm{mM}$ pH 7.0 phosphate buffer. Time dependent release of iron in the reaction mixture on addition of different doses of TBME $(100-500 \mu \mathrm{g})$ was measured spectrophotometrically at $560 \mathrm{~nm}$ for $20 \mathrm{~min}$. Reaction mixture of buffer, ferritin and ferrozine, devoid of plant extract was used as the reference solution.

\subsection{Statistical Analysis}

All data are reported as the mean \pm SD of six measurements. Statistical analysis was performed using KyPlot version 2.0 beta 15 (32 bit) and Origin professional 6.0. Comparisons among groups were made according to pair t-test. In all analyses, a p value of $<$ 0.05 was considered significant.

\section{RESULTS}

\subsection{In vitro study 3.1.1. Iron Chelation}

The formation of violet colored $\mathrm{Fe}^{2+}$-ferrozine is disrupted in presence of an iron chelator. The results (Fig. 1a and b) demonstrated that the formation of $\mathrm{Fe}^{2+}$ ferrozine complex is inhibited dose dependently in the presence of TBME and reference compound, EDTA. The $\mathrm{IC}_{50}$ values of the TBME and EDTA were $27.70 \pm 2.27$ $\mu \mathrm{g} \mathrm{mL}{ }^{-1}$ and $1.27 \pm 0.05 \mu \mathrm{g} \mathrm{mL}^{-1}$, respectively. TBME inhibited $68 \%$ of the complex formation at the highest dose, i.e., $120 \mu \mathrm{g} \mathrm{mL}^{-1}$.

\subsection{DNA Protection}

The protective effect of TBME against $\mathrm{Fe}^{2+}-\mathrm{H}_{2} \mathrm{O}_{2}$ mediated DNA breakdown was demonstrated in Fig. 2a. pUC18 supercoiled DNA was used as control (lane 1). Lane 2 comprised only of the open circular form of DNA generated by Fenton reaction. Addition of gradually increasing concentrations of TBME resulted in the restoration of DNA to the supercoiled form (lane 3-12). The results in Fig. 2b showed the dose dependant protection by TBME with a $[\mathrm{P}]_{50}$ value of $1.30 \pm 0.01 \mu \mathrm{g} \mathrm{mL}^{-1}$.

\subsection{In vivo Study \\ 3.3.1. Serum Marker Enzymes}

As shown in Table 1, increase in the levels of serum enzymes, viz., ALAT (105.92\%), ASAT (94.12\%), ALP (141.62\%) and billirubin (268.41\%), clearly signifies iron induced liver damage. Eventually, significant dose dependent decrease in the individual levels is observed in the TBME treated mice. 


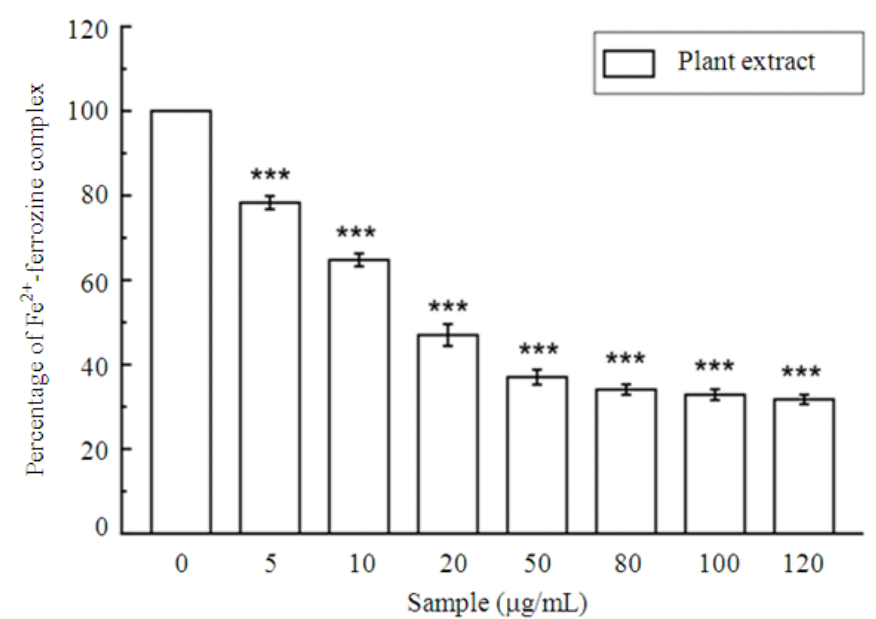

(a)

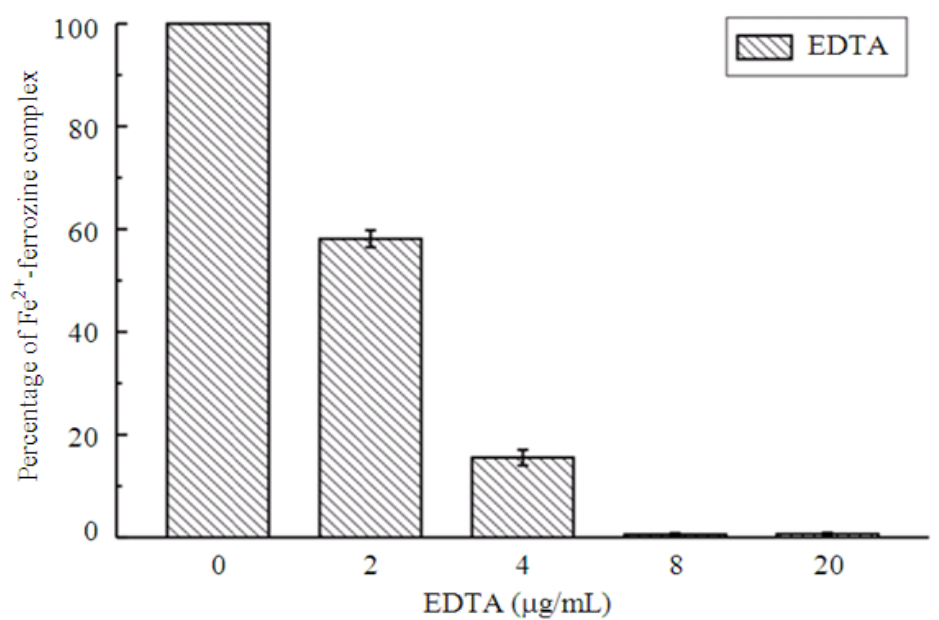

(b)

Fig. 1. Effect of (a) TBME and (b) standard EDTA on ferrozine-Fe ${ }^{2+}$ complex formation. The data expressed as \% inhibition of chromogen formation. The results are mean \pm S.D. of six parallel measurements. ${ }^{* * *}$ p $<0.001 \mathrm{vs} 0 \mu \mathrm{g} / \mathrm{ml}$

\subsection{Antioxidant Enzymes}

The overload of iron in liver results in oxidative stress and affects the decrease in the levels of antioxidant enzymes. The reduction in SOD (87\%), CAT (59\%) GST $(80 \%)$ and GSH $(35 \%)$ levels which was decreased in group C compared to group B, was found to be elevated dose dependently after treatment with TBME (Table 2).

\subsection{Lipid Peroxidation}

The present result showed, $63 \%$ increment of lipid peroxidation in liver homogenates of iron injected mice than blank was significantly reduced by 7,40 and $42 \%$ in mice fed with S50, S100 and S200 respectively (Fig. 3).

\subsection{Protein Carbonyl Content}

Protein carbonyl formation is an early marker for protein oxidation. A significant elevation (137\%) of protein carbonyl content in iron overloaded mice was found to be arrested by 25,51 and $66 \%$ in S50, S100 and S200 group respectively (Fig. 4) as treated with TBME.

\subsection{Hydroxyproline Content}

The hydroxyproline content was determined as it signifies the enhanced level of collagen content in liver fibrosis. Hydroxyproline content was observed to rise by $83 \%$ in group $\mathrm{C}$ than group B, as shown in Fig. 5. This upsurge of collagen content was gradually reduced by 42,43 and $71 \%$ in TBME treated mice (S50, S100 and S200 respectively). 


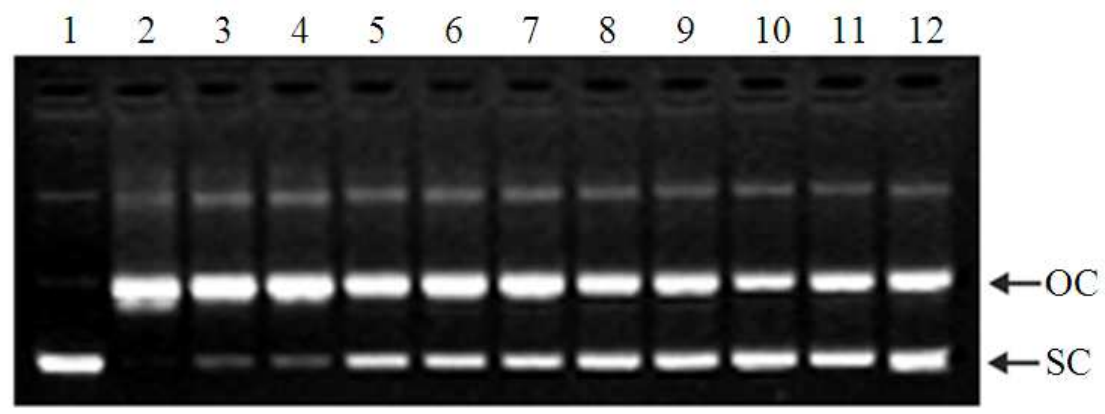

(a)

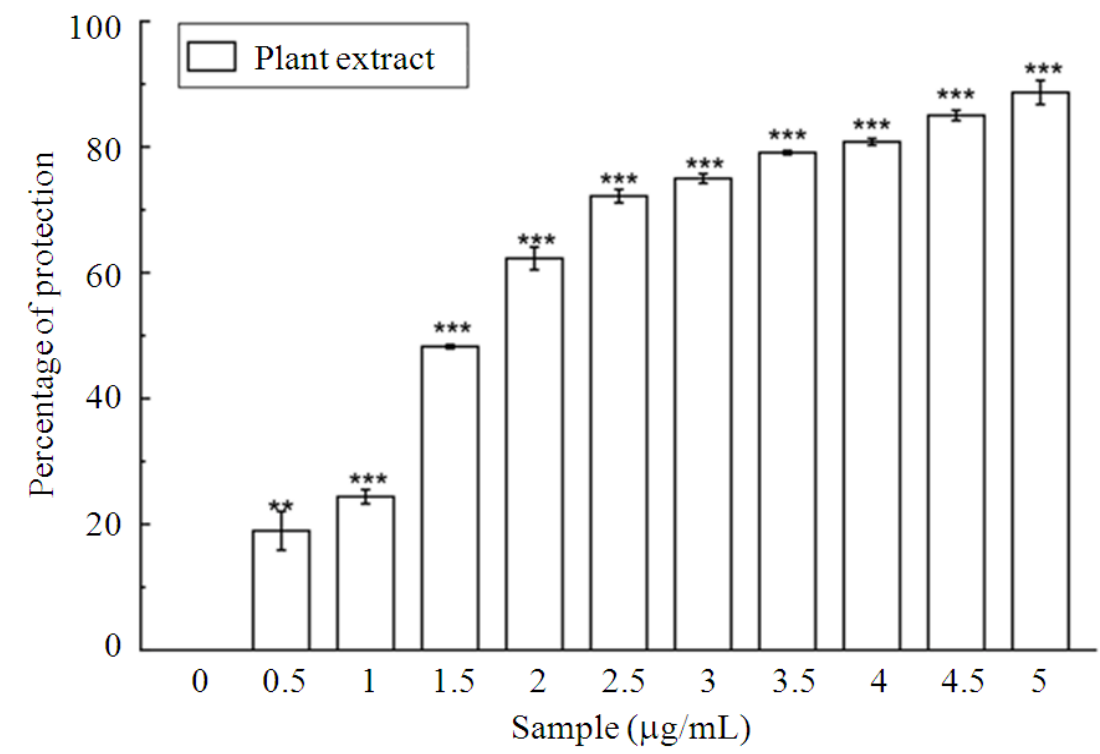

(b)

Fig. 2. Protection against oxidative damage to pUC18 by TBME. Picture of agarose gel of pUC18 DNA showing bands of supercoiled (SC) and open ciecular (OC) forms. Lanes on the gel represent: (Lane 1) control DNA (no $\mathrm{H}_{2} \mathrm{O}_{2}$ or Fe ${ }^{2+}$ ); ( $\left(\mathrm{Lane}^{2}\right.$ 2) reaction mixture without extract; (Lane 3-12) reaction mixture with extract of increasing concentration $(0.5-5 \mu \mathrm{g} / \mathrm{ml}) .{ }^{* * \mathrm{p}}$ $<0.01$ and $* * * \mathrm{p}<0.001 \mathrm{vs} 0 \mu \mathrm{g} / \mathrm{ml}$

Table 1. The effect of TBME on serum marker enzymes (ALAT, ASAT and ALP) and billirubin in iron overloaded mice

\begin{tabular}{|c|c|c|c|c|c|c|c|c|}
\hline \multirow[b]{2}{*}{ Treatment } & \multicolumn{2}{|l|}{ ALAT } & \multicolumn{2}{|l|}{ ASAT } & \multicolumn{2}{|l|}{ ALP } & \multicolumn{2}{|l|}{ Billirubin } \\
\hline & Unit/L & Change (\%) & Unit/L & Change (\%) & Unit/L & Change (\%) & Unit/L & Change (\%) \\
\hline $\bar{B}$ & $19.01 \pm 3.33$ & --- & $33.64 \pm 1.57$ & --- & $122.77 \pm 8.12$ & --- & $1.18 \pm 0.12$ & --- \\
\hline $\mathrm{C}$ & $39.15 \pm 1.51^{\mathrm{X} 1}$ & 105.92 & $65.30 \pm 3.23^{\mathrm{X} 2}$ & 94.12 & $296.64 \pm 11.16^{\mathrm{X} 3}$ & 141.62 & $4.36 \pm 0.21^{\mathrm{X} 2}$ & 268.41 \\
\hline S50 & $36.16 \pm 0.62^{\mathrm{X} 2}$ & 90.20 & $51.58 \pm 0.34^{\mathrm{X} 2 \mathrm{Y} 1}$ & 53.34 & $285.28 \pm 16.01^{\mathrm{X} 2}$ & 132.37 & $3.51 \pm 0.34^{\mathrm{X} 1 \mathrm{Y} 1}$ & 195.94 \\
\hline $\mathrm{S} 100$ & $33.91 \pm 0.69^{\mathrm{X} 1 \mathrm{Y} 2}$ & 78.37 & $42.56 \pm 0.98^{\mathrm{X} 1 \mathrm{Y} 1}$ & 26.53 & $249.22 \pm 1.94^{\mathrm{X} 2 \mathrm{Y} 1}$ & 103.00 & $3.27 \pm 0.17^{\mathrm{X} 3 \mathrm{Y} 1}$ & 176.23 \\
\hline S200 & $25.84 \pm 2.78^{\mathrm{Y} 2}$ & 35.92 & $35.66 \pm 1.91^{\mathrm{X} 1 \mathrm{Y} 2}$ & 6.00 & $169.46 \pm 30.16^{\mathrm{Y} 1}$ & 38.03 & $2.60 \pm 0.35^{\mathrm{X} 1 \mathrm{Y} 1}$ & 119.71 \\
\hline $\mathrm{D}$ & $23.55 \pm 1.39^{\mathrm{Y} 3}$ & 23.88 & $44.68 \pm 5.53^{\mathrm{X} 1 Y 1}$ & 32.81 & $151.58 \pm 9.92^{\mathrm{X} Y 3}$ & 23.47 & $1.60 \pm 0.12^{\mathrm{X} 1 \mathrm{Y} 2}$ & 34.78 \\
\hline
\end{tabular}

Values are mean \pm SD of six observations.

$X$ : significant difference from normal mice (B) group (X1: $\mathrm{p} \leq 0.05 ; \mathrm{X} 2: \mathrm{p} \leq 0.01$ and $\mathrm{X} 3$ : $\mathrm{p} \leq 0.001)$

$Y$ : significant difference from iron overloaded (C) group (Y1: $p \leq 0.05 ; Y 2: p \leq 0.01 ; Y 3: p \leq 0.001)$ 
Bibhabasu Hazra et al. / American Journal of Pharmacology and Toxicology 7 (3) (2012) 109-122

Table 2. The effect of TBME on antioxidant enzymes (SOD, CAT and GST) and non-enzymatic antioxidant, GSH in iron overloaded mice

\begin{tabular}{|c|c|c|c|c|c|c|c|c|}
\hline \multirow[b]{2}{*}{ Treatment } & \multicolumn{2}{|l|}{ SOD } & \multicolumn{2}{|l|}{ CAT } & \multicolumn{2}{|l|}{ GST } & \multicolumn{2}{|l|}{ GSH } \\
\hline & Unit/mg protein & Change (\%) & Unit/mg protein & Change (\%) & Unit/mg protein & Change (\%) & $\mu \mathrm{g} / \mathrm{mg}$ protein & Change $(\%)$ \\
\hline$\overline{\mathrm{B}}$ & $0.68 \pm 0.05$ & --- & $22.2 \pm 1.35$ & --- & $5.26 \pm 0.64$ & --- & $0.49 \pm 0.04$ & --- \\
\hline $\mathrm{C}$ & $0.09 \pm 0.02^{\mathrm{X} 3}$ & 86.98 & $9.07 \pm 0.64^{\mathrm{X} 3}$ & 59.14 & $1.05 \pm 0.19^{\mathrm{X} 3}$ & 80.01 & $0.32 \pm 0.04^{\mathrm{X} 3}$ & 34.7 \\
\hline $\mathrm{S} 50$ & $0.16 \pm 0.06^{\mathrm{X} 3}$ & 76.03 & $11.29 \pm 0.71^{\mathrm{X} 3 \mathrm{Y} 2}$ & 49.15 & $2.19 \pm 0.22^{\mathrm{X} 3 \mathrm{Y} 2}$ & 58.44 & $0.32 \pm 0.02^{\mathrm{X} 3}$ & 34.66 \\
\hline S100 & $0.45 \pm 0.04^{\mathrm{X} 2 \mathrm{Y} 3}$ & 34.02 & $15.44 \pm 0.79^{\mathrm{X3Y} 3}$ & 30.45 & $3.14 \pm 0.4^{\mathrm{X} 2 \mathrm{Y} 3}$ & 40.36 & $0.34 \pm 0.04^{\mathrm{X} 3}$ & 32.35 \\
\hline S200 & $0.47 \pm 0.03^{\mathrm{X} 3 \mathrm{Y} 3}$ & 31.36 & $16.37 \pm 0.74^{\mathrm{X} 3 \mathrm{Y} 3}$ & 26.26 & $4.13 \pm 0.41^{\mathrm{X} 2 \mathrm{Y} 3}$ & 21.44 & $0.36 \pm 0.06^{\mathrm{X} 3 \mathrm{Y} 2}$ & 27.32 \\
\hline D & $0.39 \pm 0.06^{\mathrm{X} 3 \mathrm{Y} 3}$ & 41.56 & $18.97 \pm 0.81^{\mathrm{X} 2 \mathrm{Y} 3}$ & 14.55 & $3.13 \pm 0.53^{\mathrm{X} 3 \mathrm{Y} 3}$ & 40.43 & $0.39 \pm 0.05^{\mathrm{X} 3 \mathrm{Y}}$ & 21.38 \\
\hline
\end{tabular}

Values are mean \pm SD of six observations.

$X$ : significant difference from normal mice $(B) \operatorname{group}(X 2: p \leq 0.01$ and $X 3: p \leq 0.001)$

$\mathrm{Y}$ : significant difference from iron overloaded $(\mathrm{C})$ group $(\mathrm{Y} 2 \mathrm{p} \leq 0.01 ; \mathrm{Y} 3: \mathrm{p} \leq 0.001)$

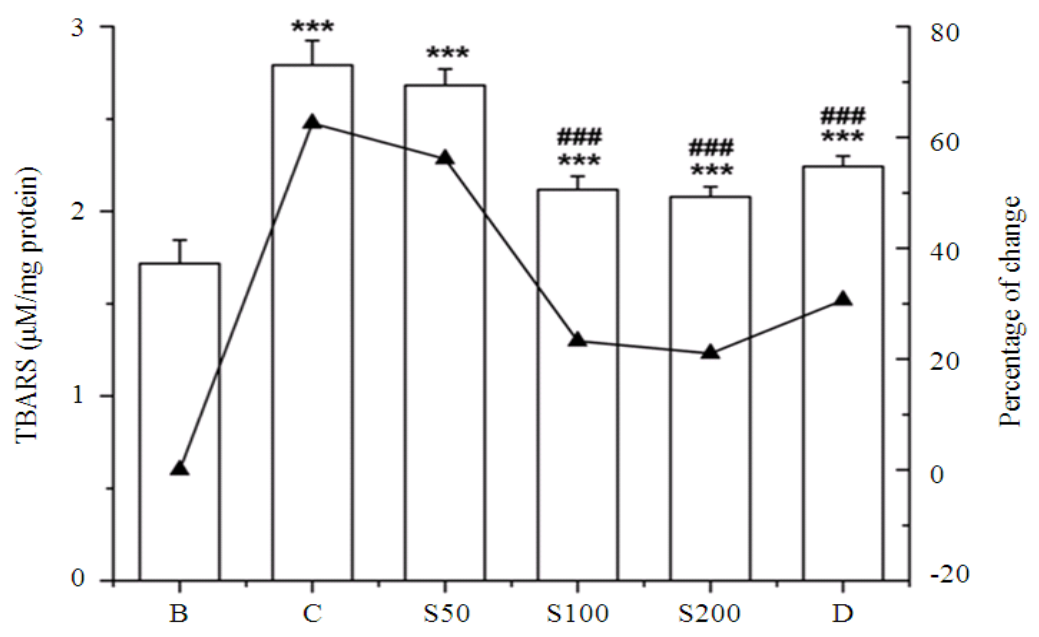

Fig. 3. Hepatic lipid peroxidation levels in different treated mouse liver. Mice were randomly divided into six groups (blank, B; control, C; $50 \mathrm{mg} \mathrm{kg}^{-1}$ b.w. TBME, S50; $100 \mathrm{mg} \mathrm{kg}^{-1}$ b.w. TBME, S100; $200 \mathrm{mg} \mathrm{kg}^{-1}$ b.w. TBME, S200; desirox group, D) and treated as described in 'experimental design' section. Values are expressed as mean \pm SD of six mice. ${ }^{* * *} p<0.001$ compared with blank and ${ }^{\# \# \#} \mathrm{p}<0.001$ compared with control

\subsection{Histopathological Analysis}

Histology of the liver sections of normal mice showed normal cell morphology with well-preserved cytoplasm, prominent nucleus and well brought out central vein (Fig. 6A). Iron-dextran control mice showed various degrees of pathological changes including hepatocellular necrosis, ballooning degeneration and loss of cellular boundaries (Fig. 6B). In contrast, the liver sections taken from TBME treated mice showed attenuation of the pathological changes and revealed marked reduction in hepatic lesions (Fig. 6C-E). Figure 6F exhibited the improved histology of liver sections taken from desirox treated group.

\subsection{Liver Iron and Serum Ferritin Levels}

Liver iron content was elevated about $151 \%$ after intraperitoneal administration injection of iron dextran.
The TBME treatment (S50, S100 and S200) evidently lowered the iron content at a level of 6,22 and $35 \%$ respectively (Fig. 7). Significant increase (182\%) of serum ferritin level in iron loaded mice was substantially reduced to 58,86 and $122 \%$ as treated with TBME dose dependently to S50, S100 S200, respectively (Fig. 8).

\subsection{Reductive Release of Ferritin Iron and its Correlation with Reducing Power}

Figure 9 showed the reductive release of ferritin iron by TBME, that was measured with a ferrous complex of ferrozine $\left[\mathrm{Fe}(\text { ferrozine })_{3}\right]^{2+}$. Control experiments without TBME produced negligible amounts of $\left[\mathrm{Fe}(\text { ferrozine })_{3}\right]^{2+}$, whereas, after dose dependant addition of TBME the $\left[\mathrm{Fe}(\text { ferrozine })_{3}\right]^{2+}$ complex formation was increased significantly with time. The correlation graph of reducing power and released ferritin iron (\%) by TBME was depicted in Fig. 10. 


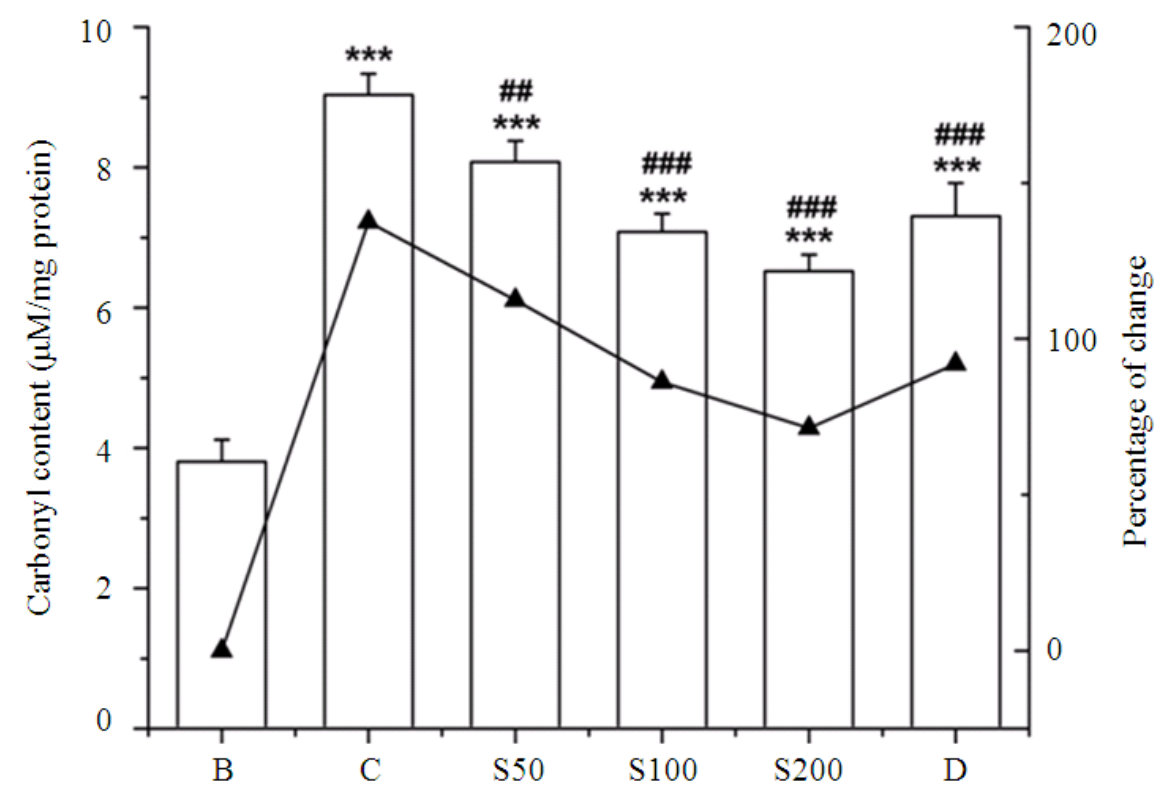

Fig. 4. Inhibitory effect of TBME on protein oxidation levels in iron overloaded mice. Mice were randomly divided into six groups (blank, B; control, C; $50 \mathrm{mg} \mathrm{kg}^{-1}$ b.w. TBME, S50; $100 \mathrm{mg} \mathrm{kg}^{-1}$ b.w. TBME, S100; $200 \mathrm{mg} \mathrm{kg}^{-1}$ b.w. TBME, S200; desirox group, D) and treated as described in 'experimental design' section. Protein carbonyl content was assayed to measure the extent of protein oxidation. Values are expressed as mean $\pm \operatorname{SD}(n=6) .{ }^{* * *} \mathrm{p}<0.001$ compared with blank and ${ }^{\# \#} \mathrm{p}<0.01$, $\# \mathrm{p}<0.001$ compared with control

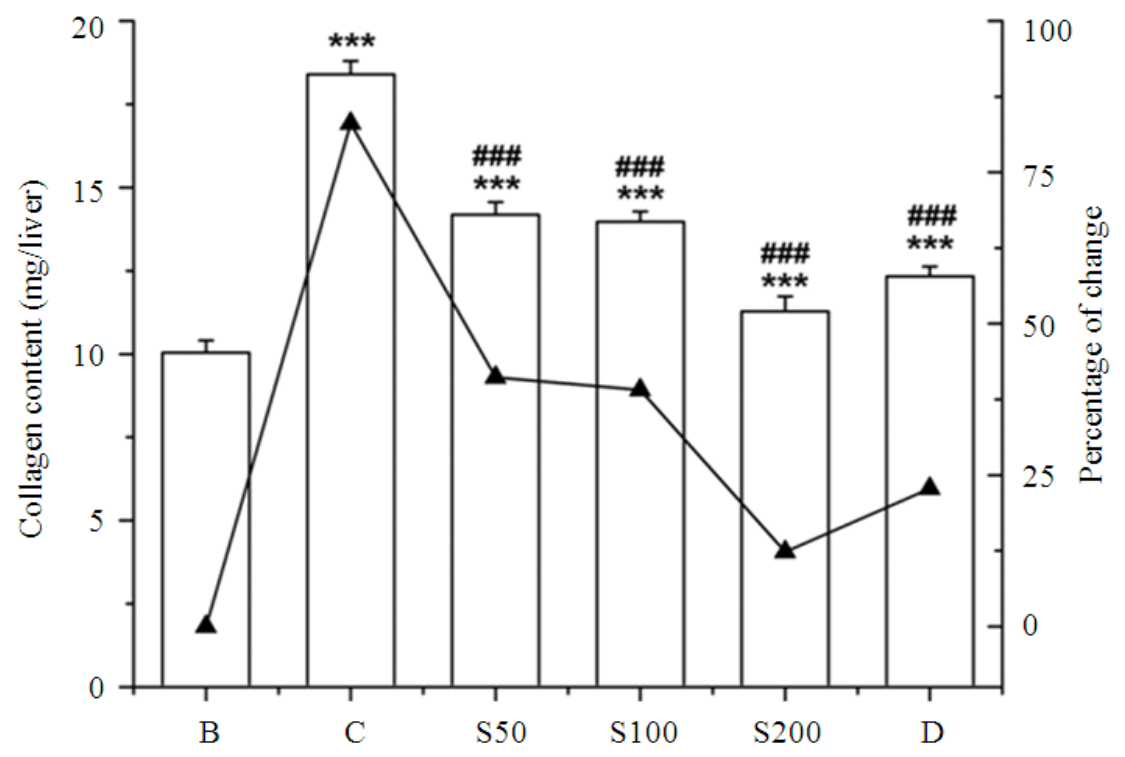

Fig. 5. Collagen content in different treated mouse liver. Mice were randomly divided into six groups (blank, B; control, C; $50 \mathrm{mg}$ $\mathrm{kg}^{-1}$ b.w. TBME, S50; $100 \mathrm{mg} \mathrm{kg}^{-1}$ b.w. TBME, S100; $200 \mathrm{mg} \mathrm{kg}^{-1}$ b.w. TBME, S200; desirox group, D) and treated as described in 'experimental design' section. Hydroxyproline content was assayed to determine the liver fibrosis. Values are expressed as mean $\pm \operatorname{SD}(n=6) .{ }^{* * *} p<0.001$ compared with blank and ${ }^{\# \# \# ~}<0.001$ compared with control 

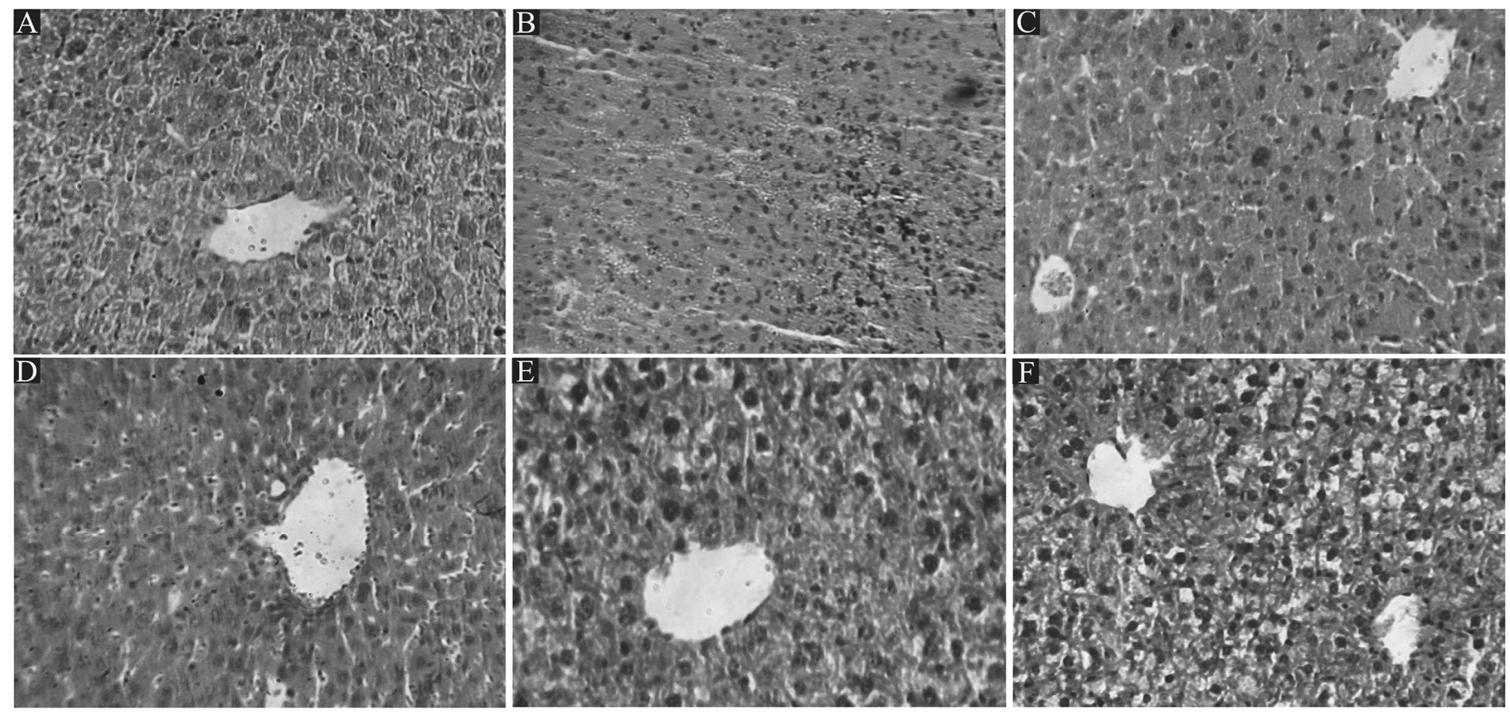

Fig. 6. Photomicrograph of mice liver sections (staining with haematoxylin and eosin) x 40; (A) Normal mice liver. (B) Iron intoxicated (iron-dextran, $100 \mathrm{mg} \mathrm{kg}^{-1}$ b.w.) liver section showing necrosis, ballooning degeneration and loss of cellular boundaries. (C) Liver section treated with iron-dextran $+50 \mathrm{mg} \mathrm{kg}^{-1}$ b.w. TBME. (D) Liver section treated with iron-dextran $+100 \mathrm{mg} \mathrm{kg}^{-1}$ b.w. TBME. (E) Liver section treated with iron-dextran $+200 \mathrm{mg} \mathrm{kg}^{-1}$ b.w. TBME. All three groups (C), (D) and (E) shows reduced hepatocellular necrosis, ballooning degeneration and inflammation. $(\mathrm{F})$ Liver section treated with iron-dextran $+20 \mathrm{mg} \mathrm{kg}^{-1}$ b.w. desirox also shows reduced necrotic area and increased number of hepatocytes

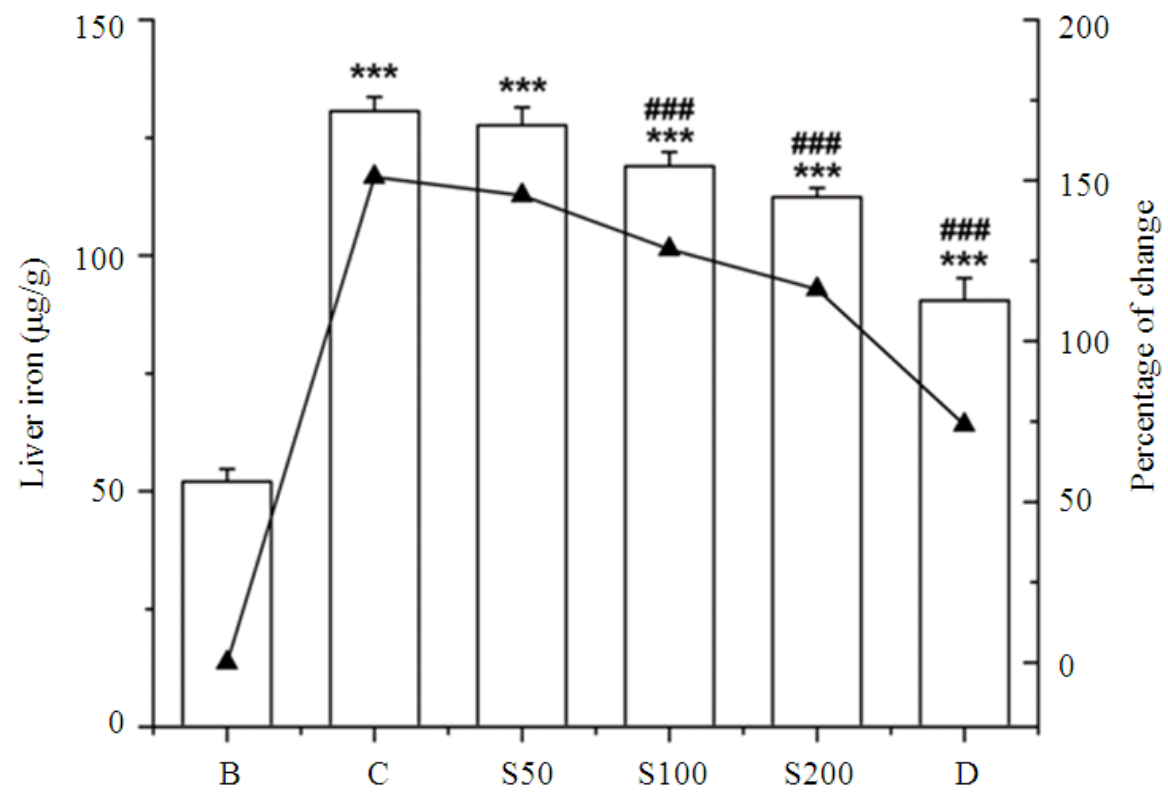

Fig. 7. Effect of TBME on hepatic iron content in different treated mouse liver. Mice were randomly divided into six groups (blank, B; control, C; $50 \mathrm{mg} \mathrm{kg}^{-1}$ b.w. TBME, S50; $100 \mathrm{mg} \mathrm{kg}^{-1}$ b.w. TBME, S100; $200 \mathrm{mg} \mathrm{kg}^{-1}$ b.w. TBME, S200; desirox group, $\mathrm{D})$ and treated as described in 'experimental design' section. Values are expressed as mean \pm SD of six mice. ${ }^{* * *} \mathrm{p}<0.001$ compared with blank and ${ }^{\# \# \# p ~}<0.001$ compared with control 


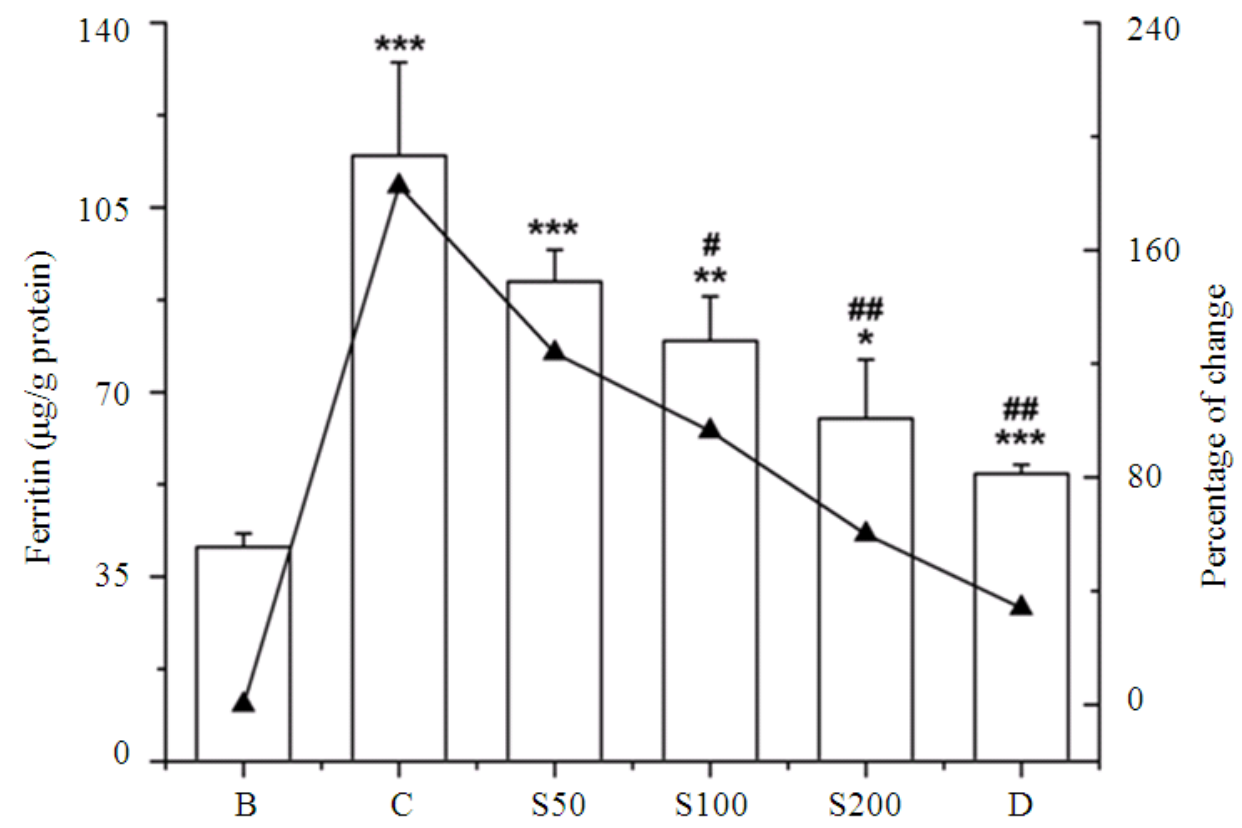

Fig. 8. Serum ferritin levels in different treated mouse. Mice were randomly divided into six groups (blank, B; control, C; $50 \mathrm{mg} / \mathrm{kg}$ b.w. TBME, S50; $100 \mathrm{mg} / \mathrm{kg}$ b.w. TBME, S100; $200 \mathrm{mg} / \mathrm{kg}$ b.w. TBME, S200; desirox group, D) and treated as described in 'experimental design' section. Serum ferritin levels were assayed to demonstrate the degrees of iron overload. Values are expressed as mean $\pm \mathrm{SD}$ of six mice. ${ }^{*} p<0.05,{ }^{* *} p<0.01,{ }^{* * *} p<0.001$ compared with blank and ${ }^{\#} p<0.05,{ }^{\# \#} p<0.01$ compared with control

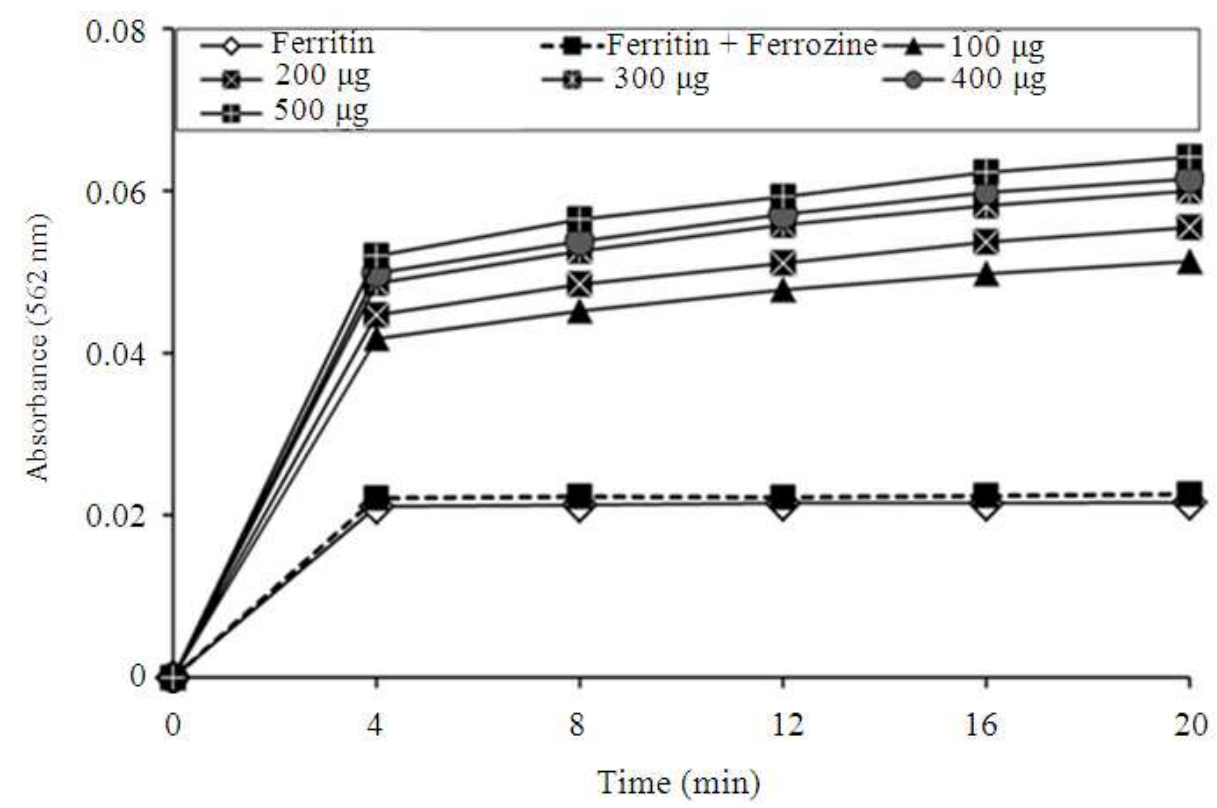

Fig. 9. Dose dependent formation of the $\left[\mathrm{Fe}\left(\text { ferrozine }_{3}\right]^{2+}\right.$ complex following release of $\mathrm{Fe}^{2+}$ from ferritin by TBME with time. The reductive release of ferritin iron was quantified by measuring the formation of the ferrous complex of ferrozine, $\left[\mathrm{Fe}(\text { ferrozine })_{3}\right]^{2+}$ at $562 \mathrm{~nm}$ using a Shimadzu UV-VIS spectrophotometer. 


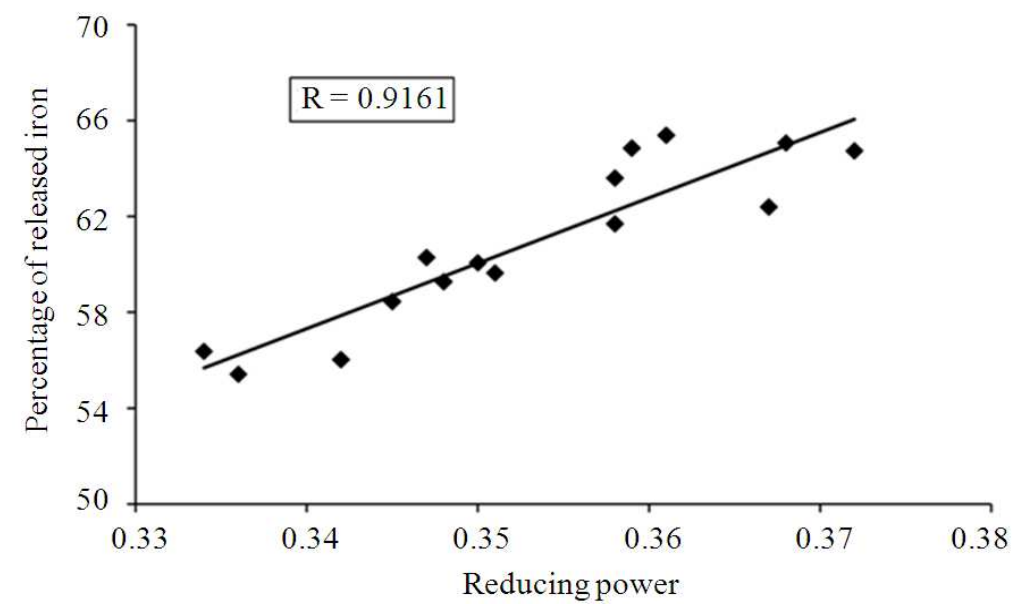

Fig. 10. Correlation of reducing power versus release of ferritin iron (\%) by TBME

Results showed a positive correlation coefficient $(\mathrm{R}=$ 0.9161 ) between the reducing power and the amount of released ferritin iron (\%), which is highly significant $(\mathrm{p}<0.001)$. The results signified the higher reducing power of TBME resulted in the release of higher amount of iron from ferritin.

\section{DISCUSSION}

Iron is the most common cofactor within the oxygen handling biological machinery and specifically, lipid peroxidation of biological membranes is the main pathogenic mechanism of iron overload induced tissue damage (Bonkovsky, 1991). In hepatic iron overload, iron begins to initiate and propagate ROS induced oxidative damage to all biomacromolecules (proteins, lipids, sugar and DNA) ultimately leading to critical failure of biological functions and cell death (Sayre et al., 2005). An effective therapeutic approach could be sequestering of catalytically active iron present in the cytosol or released by chelation from other cell iron stores (Rothman et al., 1992) and at the same time, protecting membranes from free radicals produced in the cells (i.e., antioxidant activity).

The results from Fig. 1 suggest that, TBME showed impressive results indicating that it has iron chelating activity. $\mathrm{Fe}^{2+}$-mediated Fenton reaction induced nicking of pUC18 plasmid DNA was also studied and it was observed that the DNA strand scission was significantly subdued with the addition of TBME in a dose dependent manner. The significant reduction in the formation of nicked DNA and increase in supercoiled DNA in the presence of the TBME reveal its excellent iron chelating activity.
Serum enzymes and bilirubin are the important parameters measured for the diagnosis of liver diseases. Iron overloaded hepatic injury leads to leakage of cellular enzymes into the bloodstream, resulting in amplified levels of serum ALAT, ASAT, ALP and bilirubin (Reddy and Lokesh, 1996). TBME reduced the serum enzymes as well as the total bilirubin levels, indicating its protective effect over liver and improvement in its functional efficiency.

Intrinsic defence mechanism of cells against oxidative stresses involves the range of antioxidant enzymes such as SOD, CAT, GST or compounds such as GSH (Beckman and Ames, 1998). Iron overloaded situation gives rise to major oxidative stress and lowers the levels of these enzymes involved in body's antioxidant defence system. Oral administration of TBME significantly mended the levels antioxidant enzymes and thus helping revival from iron induced damage.

The most important hypotheses for the mechanism of hepatocellular injury in chronic iron overload is the peroxidative damage to the lipid membranes of cellular organelles resulting in structural and functional alterations in cell integrity through loss of lysosomal membrane (Bonkovsky et al., 1981). The present study demonstrates the lipid peroxidation inhibiting capability of TBME and this activity supposed to be associated with its iron chelating activity.

Protein oxidation is another significant factor in the pathogenesis of iron overload induced hepatic damage. The iron overload induced ROS can lead to oxidation of protein backbone resulting in modification of catalytic and structural integrity of various important proteins (Dalle-Donne et al., 2003). The spectrophotometric 
DNPH assay was used for quantification of protein $\mathrm{CO}$ groups, as marker of oxidative damage and the results presented in this work clearly establish that TBME efficiently reduced the protein carbonyl content produced in protein oxidation.

Liver fibrosis is the excessive accumulation of extracellular proteins including collagen that occurs in most types of chronic liver diseases (Ramm and Ruddell, 2005). Iron overload cause a significant increase of hydroxyproline, which is the marker of fibrosis. Treatment with TBME significantly reduced hydroxyproline content in iron intoxicated mice, demonstrating the hepatic fibrosis inhibitory potency of the plant extract.

Histological observations are done along with the level of various biochemical parameters in circulation to mark the extent of hepatic damage. Normal hepatic parenchyma surrounding veins are observed in liver sections from normal mice, whereas extremely damaged cytoarchitecture is found to be prevalent in those from iron overloaded group. As can be found from other serum and liver parameter studies, the rejuvenation of damaged liver was corroborated in the improvement in histopathological alterations which signifies the in-situ evidence of hepatoprotective effect of plant extract.

The decrease in liver iron deposition induced by TBME treatment support its iron chelating potency. Body's iron level is positively correlated with a ubiquitous intracellular protein, ferritin, that stores iron in a non-toxic form and also helps prevent iron from mediating oxidative damage to cell constituents (Ford et al., 1984). In general, the amount of ferritin in blood reflects the extent of iron stores in the liver, making it one of the key parameters in the management of hemochromatosis and other iron overload diseases. In this study, the ferritin level was found enhanced in iron overloaded mice, whereas, the level significantly reduced after the treatment with TBME.

Within cell, ferritin served as the storage protein for excess iron in ferric state. In case of iron overload, various iron chelators are administered to attenuate the situation, but, most of these chelators have limited binding activity for ferric iron as well as iron in ferritin is not properly accessed to them. So, iron chelation therapy is dependent on the reductive release of ferritin iron, which is achieved by supplemented addition of a reducing agent such as ascorbate to increase the availability of storage iron to chelators (O'Brien, 1974). However, it is obvious that intrinsic reducing property of an iron chelator should definitely increase the efficiency of iron chelation therapy to treat iron overload. Previous results had shown the reductive ability of TBME (Hazra et al., 2010) as well as in the present study, a significant positive correlation between reducing power and iron released from ferritin has been well established. The current result exhibited the reductive ability of TBME to release ferritin iron dose dependently with time and can be used as iron chelating drug to treat iron overload.

\section{CONCLUSION}

To summarize, it can be concluded that TBME, which possess both reducing power and iron chelating activity, can reduce the toxic level of iron in iron overload mice and hence protect liver from oxidative stress and fibrosis. Serum enzyme and serum ferritin levels, both indicators of severe iron overload, are also effectively lowered owing to its administration. Taken together, the current findings may be of use in elucidating the pharmacology and application of TBME as a hepatoprotective or potential iron chelating drug in the treatment of iron overload diseases.

\section{ACKNOWLEDGEMENT}

Cipla Ltd., Kolkata, India is acknowledged for providing desirox as reference iron chelating drug for this study. The authors would also like to thank Mr. Ranjit Das and Mr. Pradip Mallik for technical assistance in sample preparation, handling of lab wares and animals in experimental procedures.

\section{REFERENCES}

Al-Refaie, F.N., B. Wonke, A.V. Hoffbrand, D.G. Wickens and P. Nortey et al., 1992. Efficacy and possible adverse effects of the oral iron chelator 1,2dimethyl-3-hydroxypyrid-4-one (L1) in thalassemia major. Blood, 80: 593-599.

Anand, K.K., B. Singh, A.K. Saxena, B.K. Chandran and V.N. Gupta, 1994. Hepatoprotective studies of a fraction from the fruits of Terminalia belerica roxb. On experimental liver injury in rodents. Phytother. Res., 8: 287-292. DOI: 10.1002/ptr.2650080507

Anand, K.K., B. Singh, A.K. Saxena, B.K. Chandran and V.N. Gupta et al., 1997. 3,4,5-Trihydroxy benzoic acid (gallic acid), the hepatoprotective principle in the fruits of Terminalia belerica-bioassay guided activity. Pharmacol. Res., 36: 315-321. DOI: 10.1006/phrs.1997.0236 
Arezzini, B., B. Lunghi, G. Lungarella and C. Gardi, 2003. Iron overload enhances the development of experimental liver cirrhosis in mice. Int. J. Biochem. Cell. Biol., 35: 486-495. DOI: 10.1016/S13572725(02)00298-4

Barry, M. and S. Sherlock, 1971. Measurement of liveriron concentration in needle-biopsy specimens. Lancet, 297: 100-103. DOI: 10.1016/S01406736(71)90838-5

Beckman, K.B. and B.N. Ames, 1998. The free radical theory of aging matures. Physiol. Rev., 78: 547-581.

Bergman, I. and R. Loxley, 1963. Two improved and simplified methods for the spectrophotometric determination of hydroxyproline. Anal. Chem., 35: 1961-1965. DOI: 10.1021/ac60205a053

Bonaventura, J., W.A. Schroeder and S. Fang, 1972. Human erythrocyte catalase: An improved method of isolation and a reevaluation of reported properties. Arch. Biochem. Biophys., 150: 606-617. DOI: 10.1016/0003-9861(72)90080-X

Bonkovsky, H.L., 1991. Iron and the liver. Am. J. Med. Sci., 301: 32-43.

Bonkovsky, H.L., J.F. Healey, P.R. Sinclair, J.F. Sinclair and J.S. Pomeroy, 1981. Iron and the liver. Acute and long-term effects of iron-loading on hepatic haem metabolism. Biochem. J., 196: 57-64.

Buege, J.A. and S.D. Aust, 1978. Microsomal lipid peroxidation. Methods Enzymol., 52: 302-310. PMID: 672633

Chopra, R.N., 1956. Glossary of Indian Medicinal Plants. 3rd Edn., CSIR, New Delhi, pp: 329.

Cook, N.C. and S. Samman, 1996. FlavonoidsChemistry, metabolism, cardioprotective effects and dietary sources. J. Nutr. Biochem., 7: 66-76. DOI: 10.1016/S0955-2863(95)00168-9

Dalle-Donne, I., R. Rossi, D. Giustarini, A. Milzani and R. Colombo, 2003. Protein carbonyl groups as biomarkers of oxidative stress. Clin. Chim. Acta, 329: 23-38. DOI: 10.1016/S0009-8981(03)00003-2

Deugnier, Y.M., O. Loreal, B. Turlin, D. Guyader and H. Jouanolle et al., 1992. Liver pathology in genetic hemochromatosis: A review of 135 homozygous cases and their bioclinical correlations. Gastroenterology, 102: 2050-2059. PMID: 1587423

Ellman, G.L., 1959. Tissue sulfhydryl groups. Arch. Biochem. Biophys., 82: 70-77. DOI: 10.1016/00039861(59)90090-6

Ford, G.C., P.M. Harrison, D.W. Rice, J.M.A. Smith and A. Treffry et al., 1984. Ferritin: Design and formation of an iron-storage molecule. Phil. Trans. R. Soc. Lond. B., 304: 551-565. DOI: 10.1098/rstb.1984.0046
Gardi, C., B. Arezzini, V. Fortino and M. Comporti, 2002. Effect of free iron on collagen synthesis, cell proliferation and MMP-2 expression in rat hepatic stellate cells. Biochem. Pharmacol., 64: 1139-1145. DOI: 10.1016/S0006-2952(02)01257-1

Habig, W.H., M.J. Pabst and W.B. Jakoby, 1974. Glutathione S-Transferases: The first enzymatic step in mercapturic acid formation. J. Biol. Chem., 249: 7130-7139.

Haro-Vicente, J.F., C. Martinez-Gracia and G. Ros, 2006. Optimisation of in vitro measurement of available iron from different fortificants in citric fruit juices. Food Chem., 98: 639-648. DOI: 10.1016/j.foodchem.2005.06.040

Hazra, B., R. Sarkar, S. Biswas and N. Mandal, 2010. Comparative study of the antioxidant and reactive oxygen species scavenging properties in the extracts of the fruits of Terminalia chebula, Terminalia belerica and Emblica officinalis. BMC Complement. Altern. Med., 10: 20-20. DOI: 10.1186/1472-688210-20

Hermes-Lima, M., E. Nagy, P. Ponka and H.M. Schulman, 1998. The iron chelator Pyridoxal Isonicotinoyl Hydrazone (PIH) protects plasmid pUC-18 DNA against - OH-mediated strand breaks. Free Radic. Biol. Med., 25: 875-880. DOI: 10.1016/S0891-5849(98)00117-8

Hynes, M.J. and M.O. Coinceanainn, 2002. Investigation of the release of iron from ferritin by naturally occurring antioxidants. J. Inorg. Biochem., 90: 1821. DOI: $10.1016 / \mathrm{S} 0162-0134(02) 00383-5$

Jadon, A., M. Bhadauria and S. Shukla, 2007. Protective effect of Terminalia belerica Roxb. and Gallic acid against carbon tetrachloride induced damage in albino rats. J. Ethnopharmacol., 109: 214-218. DOI: 10.1016/j.jep.2006.07.033

Kakkar, P., B. Das and P.N. Viswanathan, 1984. A modified spectrophotometric assay of superoxide dismutase. Indian J. Biochem. Biophys., 21: 130132. PMID: 6490072

Kapoor, L.D., 2001. Handbook of Ayurvedic Medicinal Plants. 1st Edn., CRC Press Inc., Boca Raton, ISBN10: 0849329299, pp: 416.

Kivirikko, K.I., O. Laitinen and D.J. Prockop, 1967. Modifications of a specific assay for hydroxyproline in urine. Anal. Biochem., 19: 249-255. DOI: 10.1016/0003-2697(67)90160-1

Kontoghiorghes, G.J., 2003. Do we need more ironchelating drugs? Lancet, 362: 495-496. DOI: 10.1016/S0140-6736(03)14085-8 
Lopez, M., F. Martinez, C.D. Valle, M. Ferrit and R. Luque, 2003. Study of phenolic compounds as natural antioxidants by a fluorescence method. Talanta, 60: 609-616. DOI: 10.1016/S00399140(03)00191-7

Lowry, O.H., M.J. Roesborough, A.L. Farr and R.J. Randall, 1951. Protein measurement with FolinPhenol reagent. J. Biol. Chem., 193: 265-275.

Madani, A. and S.K. Jain, 2008. Anti-Salmonella activity of Terminalia belerica: In vitro and in vivo studies. Indian J. Exp. Biol., 46: 817-821.

Niederau, C., R. Fischer, A. Sonnenberg, W. Stremmel and H.J. Trampisch et al., 1985. Survival and causes of death in cirrhotic and in noncirrhotic patients with primary hemochromatosis. N. Engl. J. Med., 313: 1256-1262. PMID: 4058506

O'Brien, R.T., 1974. Ascorbic acid enhancement of desferrioxamine-induced urinary iron excretion in thalassemia major. Ann. NY. Acad. Sci., 232: 221225. DOI: 10.1111/j.1749-6632.1974.tb20588.x

Olynyk, J., P. Hall, W. Reed, P. Williams and R. Kerr et al., 1995. A long-term study of the interaction between iron and alcohol in an animal model of iron overload. J. Hepatol., 22: 671-676. DOI: 10.1016/0168-8278(95)80222-3

Papanastasiou, D.A., D.V. Vayenas, A. Vassilopoulos and M. Repanti, 2000. Concentration of iron and distribution of iron and transferrin after experimental iron overload in rat tissues in vivo: Study of the liver, the spleen, the central nervous system and other organs. Pathol. Res. Pract., 196: 47-54. DOI: 10.1016/S0344-0338(00)80021-7

Pardo-Andreu, G.L., M.F. Barrios, C. Curti, I. Hernandez and N. Merino et al., 2008. Protective effects of Mangifera indica L extract (Vimang) and its major component mangiferin, on iron-induced oxidative damage to rat serum and liver. Pharmacol. Res., 57: 79-86. DOI: 10.1016/j.phrs.2007.12.004

Reddy, A.C.P. and B.R. Lokesh, 1996. Effect of curcumin and eugenol on iron-induced hepatic toxicity in rats. Toxicology, 107: 39-45. DOI: 10.1016/0300-483X(95)03199-P
Ramm, G.A. and R.G. Ruddell, 2005. Hepatotoxicity of iron overload: Mechanisms of iron-induced hepatic fibrogenesis. Semin. Liver Dis., 25: 433-449. DOI: 10.1055/s-2005-923315

Reznick, A.Z. and L. Packer, 1994. [38] Oxidative damage to proteins: Spectrophotometric method for carbonyl assay. Methods Enzymol., 233: 357-363. DOI: 10.1016/S0076-6879(94)33041-7

Rice-Evans, C.A., N.J. Miller and G. Paganga, 1996. Structure-antioxidant activity relationships of flavonoids and phenolic acids. Free. Radic. Biol. Med., 20: 933-956. DOI: 10.1016/08915849(95)02227-9

Rothman, R.J., A. Serroni and J.L. Farber, 1992. Cellular pool of transient ferric iron, chelatable by deferoxamine and distinct from ferritin, that is involved in oxidative cell injury. Mol. Pharmacol., 42: 703-710.

Row, L.R. and P.S. Murthy, 1970. Chemical examination of Terminalia bellerica Roxb. Ind. J. Chem., 8: 1047-1048.

Sabu, M.C. and R. Kuttan, 2009. Antidiabetic and antioxidant activity of Terminalia belerica Roxb. Indian J. Exp. Biol., 47: 270-275.

Sayre, L.M., P.I. Moreira, M.A. Smith and G. Perry, 2005. Metal ions and oxidative protein modification in neurological disease. Ann. Ist Super Sanita, 41: 143-164. PMID: 16244388

Shaila, H.P., A.L. Udupa and S.L. Udupa, 1995. Preventive actions of Terminalia belerica in experimentally induced atherosclerosis. Int. J. Cardiol., 49: 101-106. DOI: 10.1016/01675273(95)02285-5

Wolf, P.L., 1999. Biochemical diagnosis of liver disease. Ind. J. Clin. Biochem., 14: 59-90. DOI: 10.1007/BF02869152

Zhang, Y., H. Li, Y. Zhao and Z. Gao, 2006. Dietary supplementation of baicalin and quercetin attenuates iron overload induced mouse liver injury. Eur. J. Pharmacol., 535: 263-269. DOI: 10.1016/j.ejphar.2006.01.067 